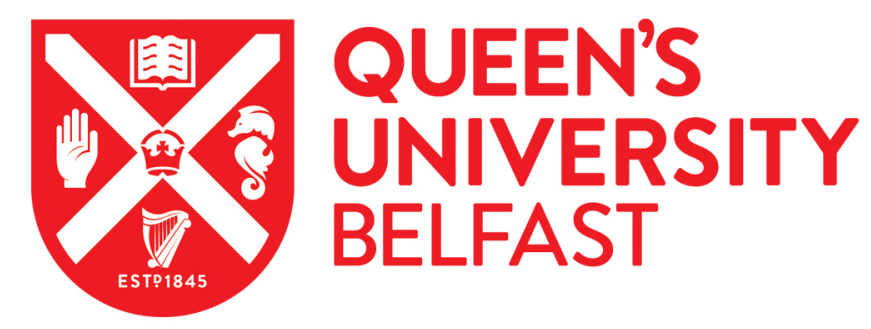

\title{
Current Developments in Fluorescent PET (Photoinduced Electron Transfer) Sensors and Switches
}

Daly, B., Ling, J., \& de Silva, A. P. (2015). Current Developments in Fluorescent PET (Photoinduced Electron Transfer) Sensors and Switches. Chemical Society Reviews, 44(13), 4203-4211.

https://doi.org/10.1039/C4CS00334A

\section{Published in:}

Chemical Society Reviews

Document Version:

Peer reviewed version

Queen's University Belfast - Research Portal:

Link to publication record in Queen's University Belfast Research Portal

Publisher rights

(C) The 2015 Authors

\section{General rights}

Copyright for the publications made accessible via the Queen's University Belfast Research Portal is retained by the author(s) and / or other copyright owners and it is a condition of accessing these publications that users recognise and abide by the legal requirements associated with these rights.

Take down policy

The Research Portal is Queen's institutional repository that provides access to Queen's research output. Every effort has been made to ensure that content in the Research Portal does not infringe any person's rights, or applicable UK laws. If you discover content in the Research Portal that you believe breaches copyright or violates any law, please contact openaccess@qub.ac.uk. 


\title{
Current Developments in Fluorescent PET (Photoinduced Electron Transfer) Sensors and Switches
}

\author{
Brian Daly, Jue Ling and A. Prasanna de Silva \\ Received (in $X X X, X X X) X$ th $X X X X X X X X X 20 X X$, Accepted Xth $X X X X X X X X X 20 X X$ \\ DOI: 10.1039/b000000x
}

\begin{abstract}
Following a brief introduction to the principle of fluorescent PET (photoinduced electron transfer) sensors and switches, the outputs of laboratories in various countries from the past year or two are categorized and critically discussed. Emphasis is placed on the molecular design and the experimental outcomes in terms of target-induced fluorescence enhancements and input/output wavelengths. The handling of single 10 targets takes up a major fraction of the review, but the extension to multiple targets is also illustrated. Conceptually new channels of investigation are opened up by the latter approach, e.g. 'lab-on-a-molecule' systems and molecular keypad locks. The growing trends of theoretically-fortified design and intracellular application are pointed out.
\end{abstract}

\section{Key learning points:}

15 (1) Being miniature, molecular sensors can open a window into the small worlds which are common in living things.

(2) Photoinduced electron transfer (PET) is an engineering-style design principle with quantitative features and a proven predictive ability, once basic photo- and electro-chemical

20 parameters are provided.

(3) Fluorescent sensors are a particularly useful category of switchable molecular devices,

(4) Molecular logic-based computation arose from fluorescent sensors research and is now seen to be an organizing principle for 25 various chemical and biochemical phenomena.

(5) Molecular logic is also beginning to find uses in small spaces where semiconductor-based information processors have difficulties.

\section{1. Introduction}

When we established the generality of the fluorescent PET (Photoinduced Electron Transfer) sensor/switch principle three decades ago, we were convinced of its semi-quantitative engineering design and of its visual appeal. ${ }^{1-3}$ After all, Weller 35 had given us a strong thermodynamics basis for the intermolecular PET process since the 1960's. He had also recognized the competition between fluorescence and PET for the deactivation of the excited state. ${ }^{4,5}$ The kinetic aspects had received Marcus' crucial input., ${ }^{5,6}$ So our role had been to apply 40 the competition scenario twice under intramolecular conditions once when the sensor/switch was devoid of the analyte/target species and once again when the latter was present - so that the fluorescence signal would alter significantly between the two situations. Such a change in a fluorescence signal would be easily 45 observable by people, with or without instrumental augmentation. However, it would have been foolhardy in the 1980's to predict the wide and sustained uptake of the principle by laboratories worldwide that we see today (Figure 1). ${ }^{7-9}$ The circumstances of the early days has been reported in two reviews. ${ }^{10,11}$ 'Hardly a

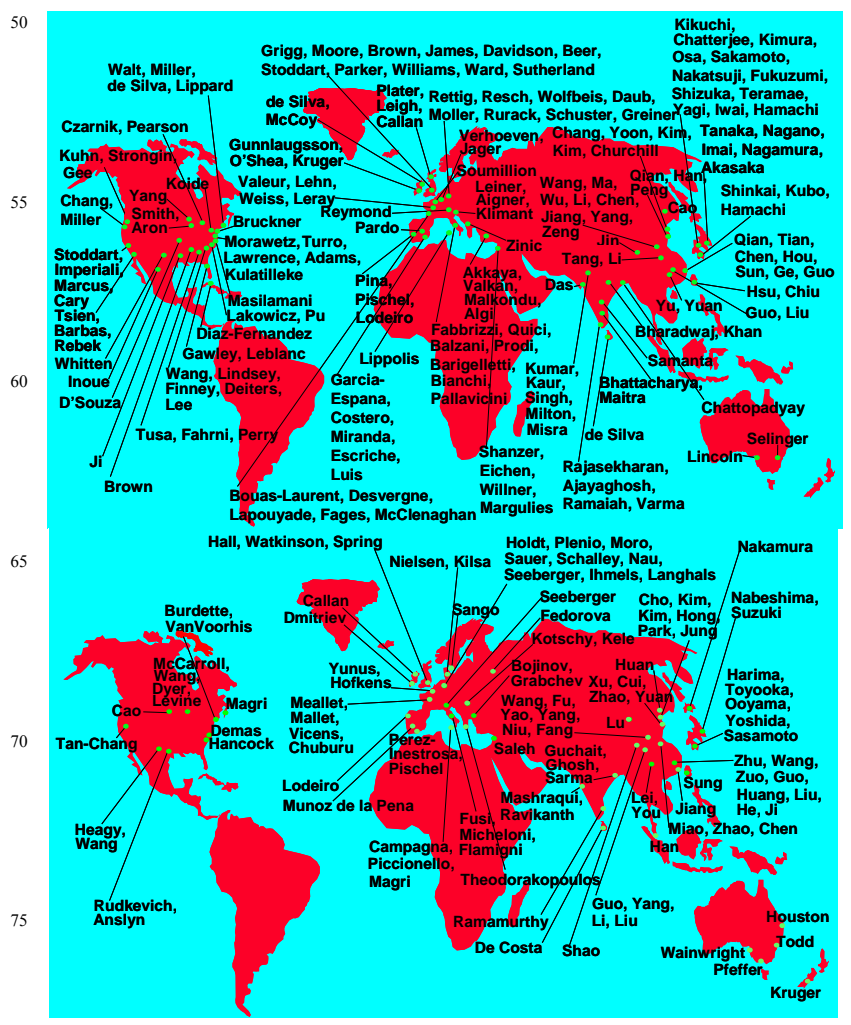

Figure 1a and 1b. Approximate world maps of sources of 80 fluorescent PET sensors and switches aimed at single targets. Only the names of corresponding authors from the literature are given.

week goes by without a fluorescent PET sensor being reported' 85 was our observation in $2009,{ }^{11}$ and the situation is no different in 2014. Indeed, 59 references from 2014 are specifically cited in this review, with a substantial fraction coming in for detailed 
discussion, subject to space limitations. Of course, older references are cited in strength, so that the historical threads are fully exposed, theoretical foundations are suitably developed, and adequate contexts are set out from the viewpoint of our 5 experience in establishing the generality of the field.

Binary possibilities arose from instances where the fluorescence signal change was large enough to be considered as 'off-on' or 'on-off'. These took on added significance in a world which was increasingly conscious of information technology. ${ }_{10}$ Thus, molecular information processors became possible in 1993..$^{2}$ Although a myriad ways became available for molecules to be interrogated like semiconductor devices, the fluorescent PET sensor/switch principle provided the first approach and still remains a very profitable avenue..$^{13-18}$

15 In this review, we concentrate on fluorescent PET sensors and switches which have appeared during the last year or so, while offering some context from the past. The emphasis of this review is on small-molecule sensors.
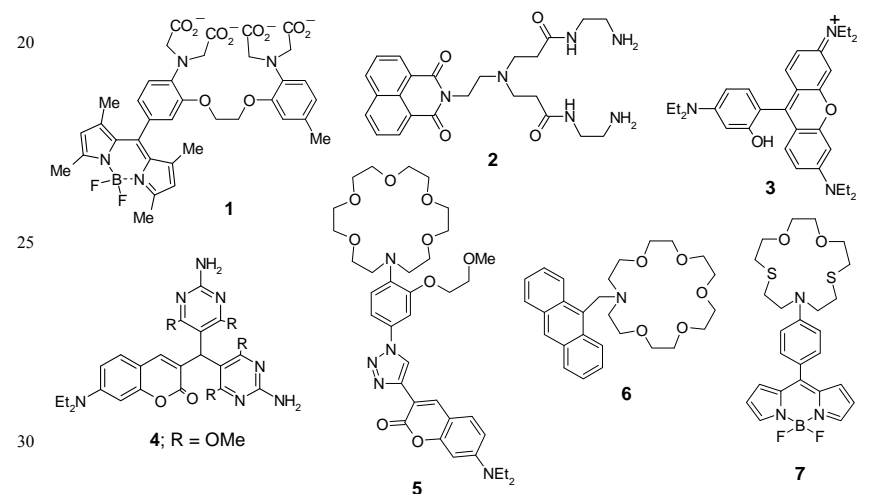

\section{The fluorescent PET sensor/switch principle}

It might be prudent to give a brief summary of the principle at the 35 outset. In its commonest manifestation, a fluorophore is weakly coupled electronically with a receptor so that the two modules quantitatively maintain their individual properties in the photochemistry and supramolecular chemistry spheres. The two modules are chosen so that the excited fluorophore has sufficient 40 energy to transfer an electron, say, from the receptor to the fluorophore. This means that the excited state energy is larger than the sum of the moduli of the oxidation and reduction potentials of the receptor and fluorophore respectively. If the experimental redox potentials are unavailable, modern quantum 45 chemistry software can supply adequate estimates of the energies of the frontier orbitals of the two modules, and these can do the job almost as well. When the analyte/target species was bound to the receptor module, the oxidation potential would be significantly increased, ${ }^{19}$ so that the PET process fails and ${ }_{50}$ fluorescence re-asserts itself.

While electrochemical experiments and frontier orbital energy calculations are very useful as design tools, experimental proof of fluorescent PET sensor/switch behaviour requires the observation of radical ion species following fast laser photolysis. While

${ }_{55}$ Weller provided such evidence in intermolecular PET, ${ }^{4}$ intramolecular PET sensor/switch systems have been studied rarely. ${ }^{20,21}$ The laboratories of McClenaghan and Jonusauskas join forces to provide a timely example $1 .^{22} \mathrm{~A}$ broad absorption between 520 and $570 \mathrm{~nm}$, which corresponds to the previously

60 known radical anion band of the borodipyrromethene (BODIPY) fluorophore, appears and decays within $1 \mathrm{~ns}$ in THF solution. The radical cation of the receptor also appears, though less unequivocally, at $330 \mathrm{~nm}$. The radical ions recombine at longer times to produce the fluorophore's triplet excited state. A very 65 fast PET rate of $3.3 \times 10^{12} \mathrm{~s}^{-1}$ could be calculated under these conditions.

\section{Proton targets}

It is apt that protons represent the first target to consider. Their 70 binding to appropriate receptors (Bronsted bases) is less complex than those of larger ions. Also, their role near membranes ${ }^{23,24}$ in bioenergetics is disproportionately important ${ }^{25}$ given their small size.

A first-generation dendron containing a tertiary amine is 75 employed as a receptor by Bojinov's team within 2. ${ }^{26}$ When excited at $302 \mathrm{~nm}$, the emission at $397 \mathrm{~nm}$ shows a $\mathrm{H}^{+}$-induced fluorescence enhancement $\left(\mathrm{FE}^{+}\right)$of 7.6 with an associated $\mathrm{pK}_{\mathrm{a}}$ of 9.5. Research on related naphthalimide fluorophores is available. ${ }^{27}$ Interestingly, transition metal ions do not interfere 80 significantly with 2's performance perhaps because they would be held rather distant from the fluorophore.

Emission in the redder regions of the spectrum is preferred for intracellular studies, owing to less scattering and better penetration. Sun, Ge and co-workers provide an easily ${ }_{85}$ synthesized example $3,{ }^{28}$ where x-ray crystallographic proof is available for the substantial rotation of the plane of the aniline ring with respect to the xanthene tricycle. Thus, PET across a virtual spacer from the aniline to the xanthene fluorophore becomes feasible, especially because the calculated HOMO of the 90 aniline lies higher in energy than the HOMO of the xanthene. Thus, excitation of an electron from the xanthene HOMO would leave a vacancy into which another electron can be transferred from the aniline HOMO. Protonation of the aniline removes this PET process and indeed, the fluorescence at $592 \mathrm{~nm}$ gives $\mathrm{FE}_{\mathrm{H}^{+}}=$ ${ }_{95} 400\left(\mathrm{pK}_{\mathrm{a}}=4.7\right)$ when excited at $535 \mathrm{~nm}$. Many other cell constituents do not interfere and acidic lysosomal regions of $\mathrm{HeLa}$ cells show up nicely in fluorescence microscopic experiments.

We return to the blue region where sensor $\mathbf{4}^{29}$ responds in an 100 'on-off' (or NOT logical) manner to $\mathrm{H}^{+}$, following protonation of one pyrimidine and the diethylamino group. The second pyrimidine, which is nearby, does not protonate owing to electrostatic considerations. ${ }^{1} \mathrm{H}$ nmr evidence is offered for this double protonation. An $\mathrm{H}^{+}$-induced blue shift of $70 \mathrm{~nm}$ in the 105 ultraviolet spectrum is also suggestive. Frontier orbital energy calculations show that, upon protonation of the diethylamino group, the fluorophore HOMO falls in energy below the HOMO of the unprotonated pyrimidine ring. Thus PET can occur from the unprotonated pyrimidine to the protonated aminocoumarin. 110 The fluorescence at $460 \mathrm{~nm}$ indicates $\mathrm{FE}_{\mathrm{H}^{+}}=0.025\left(\mathrm{pK}_{\mathrm{a}}=2.1\right)$ when excited at $385 \mathrm{~nm}$. E. Coli grown in media as acidic as $\mathrm{pH}$ 0.6 shows appropriately weak fluorescence from 4 within.

\section{Alkali and alkaline earth ion targets}

115 The next logical step would be to consider light metal ions. Since the McClenaghan-Jonusauskas case $\mathbf{1}^{22}$ carries the famous Tsien receptor for $\mathrm{Ca}^{2+}$, it is no wonder that a $\mathrm{FE}_{\mathrm{Ca} 2}+$ value of 122 $\left(\log \beta_{\mathrm{Ca} 2+}=6.3\right)$ is found by monitoring the fluorescence at 514 $\mathrm{nm}$ while exciting at $475 \mathrm{~nm}$. As is the trend these days, frontier 120 orbital energy calculations produce the appropriate HOMO energy ordering, i.e. the HOMO energy of the receptor lies higher in energy than the HOMO of the fluorophore.

$\mathrm{K}^{+}$is the target for a strong team assembled by Holdt. ${ }^{30}$ They construct 5, which interestingly shares the diethylaminocoumarin 125 motif with 4. ${ }^{29}$ However, this unit is clicked onto a 
phenylazacrown receptor and results in an excellent selectivity for the target over several potential interferents like $\mathrm{Na}^{+}$and $\mathrm{H}^{+}$at their normal intracellular levels. This is a very positive result for such a simple receptor and therefore it is not surprising that 5 sensor 5 succeeds inside NRK cells. The fluorescence at $493 \mathrm{~nm}$ gives $\mathrm{FE}_{\mathrm{K}+}=3.0\left(\log \beta_{\mathrm{K}+}=1.5\right)$ when excited at $420 \mathrm{~nm}$, due to $\mathrm{K}^{+}$-induced arrest of PET across the virtual spacer.

$\mathrm{K}^{+}$was also the target, though not so selectively, for our very old work with 6. ${ }^{31}$ This work, along with that of Desvergne, 10 Bouas-Laurent and Lehn ${ }^{32}$ launched fluorescent PET sensors and switches as an important branch of supramolecular chemistry. Now, Wang and co-workers ${ }^{33}$ support the outcome of $\mathbf{6}$ by performing a detailed theoretical study of the PET process from the azacrown ether receptor to the anthracene fluorophore.
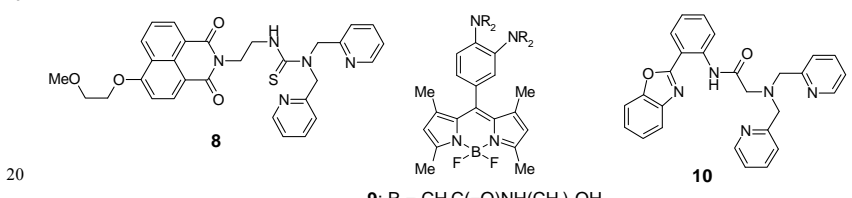
9; $\mathrm{R}=\mathrm{CH}_{2} \mathrm{C}(=\mathrm{O}) \mathrm{NH}\left(\mathrm{CH}_{2}\right)_{2} \mathrm{OH}$
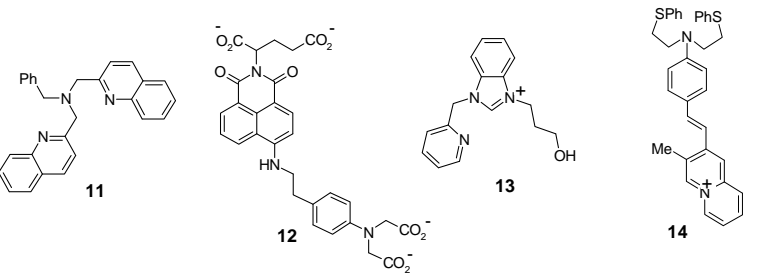

\section{Transition metal and post-transition metal ion targets}

Now we move to heavier metal ions. For instance $\mathrm{Pd}^{2+}$ has been fluorimetrically sensed only rarely, ${ }^{34}$ but Kaur, Singh and 35 colleagues build a phenylazacrown receptor carrying two sulfurs which communicates via a virtual spacer with the BODIPY fluorophore $^{35}$ (as seen in $\mathbf{1}^{22}$ ). The soft base atoms in the receptor prepare 7 for selective binding to soft metals like $\mathrm{Pd}^{2+}$, though the impressive selectivity achieved cannot be explained away so 40 simply. Indeed, $\mathrm{Hg}^{2+}$ is the only significant interferent which could be masked with cysteine. The fluorescence at $520 \mathrm{~nm}$ gives $\mathrm{FE}_{\mathrm{Pd} 2+}=57\left(\log \beta_{\mathrm{Pd} 2+}=7.2\right.$, in $\left.\mathrm{MeCN}\right)$ when excited at $488 \mathrm{~nm} .{ }^{35}$ Frontier orbital energy calculations for the separate receptor and fluorophore support the $\mathrm{Pd}^{2+}$-induced arrest of the PET process.

45 In spite of 7's relative insolubility in water, the authors bravely conduct microscopy studies in a breast cancer cell line.

When it comes to metal ion receptors, ${ }^{7}$ nitrogen holds a near monopoly, ${ }^{36}$ in spite of its known $\mathrm{pH}$ sensitivity. Finney, Deiters and their team ${ }^{37}$ introduce sulfur-based thiourea 8 as a monopoly 50 breaker, which fits a PET switch design. Here, the thiourea serves as PET donor to the naphthalimide fluorophore across the dimethylene spacer. The pyridyl groups are too remote from the fluorophore to cause any noticeable $\mathrm{pH}$-sensitivity in the emission performance. The fluorescence at $446 \mathrm{~nm}$ gives $\mathrm{FE}_{\mathrm{Hg} 2+}$ ${ }_{55}=7.4\left(\log \beta_{\mathrm{Hg} 2+}=6.1\right.$ in methanol $)$ when excited at $367 \mathrm{~nm}$. Unequivocally $\mathrm{Hg}^{2+}$-dependent fluorescence microscopy shows the successful application of $\mathbf{8}$ within HeLa cells.

An important milestone in fluorescent PET sensor development is reached when these sensors are embraced by the environmental 60 analytical chemistry community. A similar instance involving the medical diagnostics community is available. ${ }^{38,39}$ The Muñoz de la Peña laboratory has published valuable research on classical fluorescent analytical reagents which has been inspirational to us. ${ }^{40}$ So it is lovely to be able to report their exploitation of $\mathbf{9},{ }^{41}$
65 which was first reported by Wang and Qian. ${ }^{42,43}$ The fluorescence at $538 \mathrm{~nm}$ gives $\mathrm{FE}_{\mathrm{Hg} 2+}=9\left(2: 1\right.$ complex $\left.\mathrm{Hg}^{2+}: \mathbf{9}\right)$ when excited at $515 \mathrm{~nm}$ in water. The need to perform measurements while minimizing light exposure is not surprising since the PET channel designed into the sensor can lead to photodecomposition 70 if the intramolecular radical ion recombination is not fast enough.

Huan and colleagues describe sensor $\mathbf{1 0}^{44}$ which shares the bispicolylamine moiety not only with $\mathbf{8}^{37}$ but also with many other $\mathrm{Zn}^{2+}$-sensitive fluorescent PET systems. ${ }^{11}$ Particular mention needs to be made of S. A. de Silva's first example of a 75 bispicolylamine-based fluorescent PET sensor for $\mathrm{Zn}^{2+}$. ${ }^{45}$ The fluorescence of $\mathbf{1 0}$ at $443 \mathrm{~nm}$ gives $\mathrm{FEZn} 2+_{2}=5.1(\log \beta \mathrm{Zn} 2+=5.0$, in 1:1 MeCN:water) when excited at $353 \mathrm{~nm}$. $\mathrm{Cu}^{2+}$ displaces $\mathrm{Zn}^{2+}$ from $10 . \mathrm{Zn}^{2+}$ owing to the well-known Irving-Williams stability series $^{46}$ and the emission disappears again. The final outcome is 80 probably due to electronic energy transfer (EET) from the fluorophore to the $\mathrm{Cu}^{2+}$ centre, if we go by the conclusions of earlier studies. $^{47}$

$\mathrm{Zn}^{2+}$-induced arrest of PET from an amine to the quinoline fluorophore is responsible for the fluorescence of 11 at $382 \mathrm{~nm}$ ${ }_{85}$ giving a $\mathrm{FE}_{\mathrm{Zn} 2+}$ of $34\left(\log \beta_{\mathrm{Zn} 2+}=4.5\right)$ when excited at $311 \mathrm{~nm}$ in MeCN. ${ }^{48}$ Importantly, $\mathrm{Cd}^{2+}$ has virtually no effect. However, the receptor property of the quinoline fluorophore is responsible for the ICT (internal charge transfer) aspects of the sensor behaviour, e.g. $\mathrm{Zn}^{2+}$-induced changes in the absorption spectrum. The

90 bispicolylamine moiety hiding within $\mathbf{1 1}$ also needs to be highlighted.

12 due to Yang's team, including He and Chen, ${ }^{49}$ is a careful modification of Gunnlaugsson's previous $\mathrm{Zn}^{2+}$ sensor, ${ }^{50}$ where attention is paid to parameters such as wet storage which only 95 hardened industrialists would realize. The fluorescence at 550 $\mathrm{nm}$, when excited at $470 \mathrm{~nm}$, gives $\mathrm{FE}_{\mathrm{Zn} 2+}=50\left(\log \beta_{\mathrm{Zn} 2+}=4.6\right)$. The glutamate side chain aids cell permeability in its diester form and later in its dicarboxylate form, helps retention in the cytosol of HeLa cells. Gunnlaugsson's design components of the 100 aminonaphthalimde fluorophore, the N-phenyliminodiacetate receptor and the PET switching mechanism itself are maintained.

Though equipped with only pyridyl and alcohol units as potential receptors, the fluorescence of $13^{51}$ at $375 \mathrm{~nm}$ gives $\mathrm{FEFe}{ }^{+}=0.06\left(\log \beta_{\mathrm{Fe} 3+}=3.2\right)$ when excited at $272 \mathrm{~nm}$ in water, 105 with PET and/or EET from the fluorophore to the bound $\mathrm{Fe}^{3+}$ being responsible.

Like Ihmels' sensing of DNA-bounded $\mathrm{Hg}^{2+}, 52$ Zeng et al measure $\mathrm{Ag}^{+}$near DNA with 14. ${ }^{53}$ 14's fluorescence at $590 \mathrm{~nm}$, when excited at $455 \mathrm{~nm}$, gives $\mathrm{FE}_{\mathrm{Ag}^{+}}=28\left(\log \beta_{\mathrm{Ag}^{+}}=4.6\right)$. Like 110 Finney's $\mathbf{8},{ }^{37}$ the PET donor of $\mathbf{1 4}$ is based on sulfur. The polyanionic nature of DNA concentrates $\mathrm{Ag}^{+}$in 14 's vicinity. Although, the intercalation of cationic 14 within DNA suppresses rotation around the styryl alkene linkage, the drop of fluorescence intensity indicates that PET is accelerated at this stage. 115

\section{Anion targets}

This review would be lacking unless some reports on anion targets are considered from the past year. Like $\mathbf{1},{ }^{22} \mathbf{7}^{35}$ and $\mathbf{9},{ }^{41}$ Madhu and Ravikanth's $15^{54}$ focuses on the BODIPY 120 fluorophore. However, $\mathbf{1 5}$ has an appended benzimidazole which engages in N-H...F hydrogen bonding with the two fluorines on the boron centre. X-ray crystallography shows that this hydrogen bonding also leads to planarization of the entire structure (except the two fluorines). There is a large $\mathrm{F}^{-}$-induced alteration in the 125 absorption spectrum which causes a pink-to-blue colour change. The fluorescence at $592 \mathrm{~nm}$ in $\mathrm{MeCN}$, when excited at $530 \mathrm{~nm}$, gives $\mathrm{FEF}_{\mathrm{F}-}=0.11\left(\log \beta_{\mathrm{F}-}=6.4,1: 2 \quad 15: \mathrm{F}^{-}\right)$, though the absorbance changes need to be borne in mind. The $\mathrm{F}^{-}$-induced 
fluorescence quenching is caused by deprotonation of the benzimidazole so that the latter anionic unit can rotate out of the BODIPY plane. Now PET can take place from the benzimidazole anion to the BODIPY unit. The HF side-product picks up an 5 additional $\mathrm{F}^{-}$to give $\mathrm{FHF}^{-}$. Addition of $\mathrm{H}^{+}$reverses the above effects.

A similar PET process from a deprotonated receptor to a BODIPY fluorophore is implicated in the case of $\mathbf{1 6}$ due to Rurack and coworkers. ${ }^{55}$ In this case, $\mathrm{F}^{-}$-induced deprotonation 10 of a N-(4-nitrophenyl)thiourea is involved. The fluorescence of 16 at $513 \mathrm{~nm}$ gives $\mathrm{FEF}_{\mathrm{F}-}=0.47\left(\log \beta_{\mathrm{F}-}=4.7\right)$ when excited at $482 \mathrm{~nm}$ in 1:1, DMSO:water at $\mathrm{pH} 6.8$. Test strips containing 16 can be used to measure $\mathrm{F}^{-}$in lateral-flow readers, which augurs well for the future. Older $\mathrm{F}^{-}$sensors which share some structural 15 features and operate in mixed aqueous solution are known. ${ }^{56,57}$

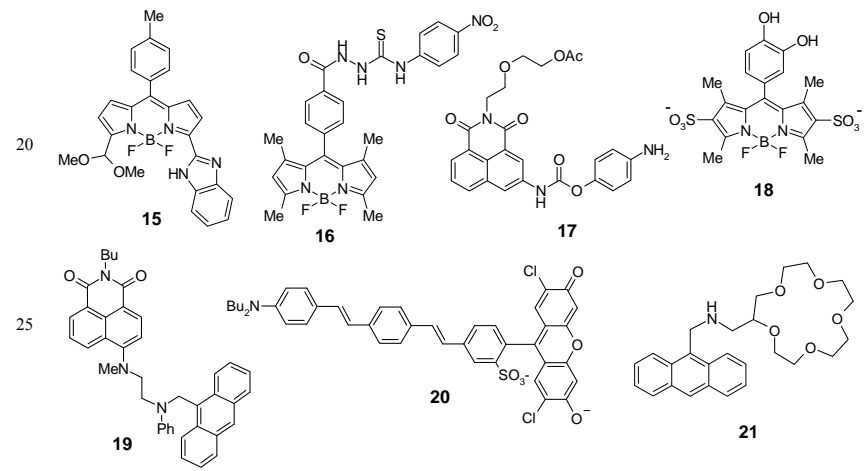

\section{Reactive oxygen targets}

The fluorescent PET sensor/switch principle can also be applied in the form of fluorescent PET reagents when the target reacts irreversibly as in the case of various thiols ${ }^{58-63}$ Some of these 35 improve selectivity towards cases like glutathione versus simpler thiols by cleverly employing AND logic involving connected chemical inputs. ${ }^{64}$ However, we choose to focus on reactive oxygen species (ROS) at this time. ${ }^{65-68} \mathbf{1 7}$, due to Xu, Qian and colleagues, has PET from the aminophenoxy moiety to the 40 naphthalimide which renders $\mathbf{1 7}$ non-emissive. ${ }^{65}$ Hypochlorite oxidizes the aminophenoxy unit to a separate quinoneimine and leaves a naphthalimide with a carbamate in the 3-position which emits at $460 \mathrm{~nm}$ when excited at $340 \mathrm{~nm}($ FEocl- $=71)$. This partly decarboxylates to yield a 3-aminonaphthalimide which 45 emits at $570 \mathrm{~nm}($ FEoCl- $=63)$. Only the $460 \mathrm{~nm}$ component of this dual emission is found when peroxynitrite is the ROS. Other ROS like hydrogen peroxide produce no emission at all. Even $7 \times 10^{-7} \mathrm{M}$ hypochlorite can be detected in this way, even inside HeLa cells.

so Kim and Kim's $\mathbf{1 8}$ is non-fluorescent because of PET from the catechol moiety to the BODIPY unit. ${ }^{66}$ Hypochlorite oxidizes the catechol unit to a $o$-quinone. Apparently, the possible PET to the latter group from the BODIPY unit does not occur. Though further analysis of this issue would be welcome, the experimental

55 upshot is a rather selective FEocl- value of 80 with a limit of detection of $3 \times 10^{-7} \mathrm{M}$.

\section{Physicochemical property targets}

A consortium of $\mathrm{Xu}$, Cui, Qian, Spring and colleagues ${ }^{70}$ exploit ${ }_{60}$ the flailing rotatory motion inherent in the generation of twisted intramolecular charge transfer (TICT) excited states ${ }^{71}$ and the conformation-dependent PET to develop the viscosity sensor 19 and apply it to intracellular microscopy studies. Fluorescence intensity and lifetime are both put to use. Nice viscosity maps
65 with organelle-level resolution are produced. The thermodynamics of TICT states $^{72}$ and PET processes ${ }^{4}$ are very similar since a radical ion pair is produced in each case, though there are subtle differences in a sensor context. ${ }^{73}$ Structurally, 19 contains two fluorophores - aminonaphthalimide and anthracene 70 and an electron donor aniline. The latter shows no metal binding ability and displays a $\mathrm{pK}_{\mathrm{a}}$ value of 3.1. So, protonation-based interference would not be expected even in some of the most acidic regions, i.e. lysosomes with $\mathrm{pH}$ values around 5. However, a word of caution would be advised here since organelle 75 membranes can easily concentrate $\mathrm{H}^{+}$at nanometric distances near them by several orders of magnitude, thus encroaching on 19's $\mathrm{pK}_{\mathrm{a}}$ value of 3.1. Such effects are known from model membrane studies. ${ }^{23,24}$ Classical optical microscopy images would not be able to resolve such effects. The presence of two 80 fluorophores leads to electronic energy transfer (EET) effects too, and almost exactly this pair has been studied in a ratiometric PET/EET-based $\mathrm{pH}$ sensor context before. ${ }^{74}$ The presence of the anthracene emission serves as an internal reference for the viscosity-dependent emission of the aminonaphthalimide moiety.

${ }_{85}$ As seen in other PET sensors, ${ }^{75,76}$ the fluorescence of $\mathbf{1 9}$ has a substantial polarity effect, i.e. the total quantum yield goes from 0.004 in water to 0.14 in toluene, though the viscosity effect is clearly present too, as seen in the corresponding value of 0.36 in glycerol. Therefore, another word of caution would be that 90 organelle membranes can have polarities at least as low as toluene, so that nanoenvironments nearby (which are unresolvable by conventional optics) would cause switching 'on' of aminonaphthalimide emission. Indeed, such polarity-related interference has led to the failure of rather hydrophobic $\mathrm{pH}$

95 sensors to operate correctly inside cells, by remaining switched 'on' at whatever $\mathrm{pH}$ value. ${ }^{.7}$

An aniline electron donor is also found in Tsien's PET sensor 20 for membrane potential ${ }^{78,79}$ in live cells. The relatively large fluorescence intensity response shown by $\mathbf{2 0}$ when cells are 100 depolarized allows it to produce images of membrane potential with submicrometer and microsecond resolution. Thus it forms a nice complement to classical electrophysiology. 20 positions itself in cell membranes owing to its hydrocarbon chains and general hydrophobicity. The oligoalkene section acts as a ${ }_{05}$ molecular wire to facilitate the PET process. ${ }^{80}$ However, the hydrophilic ionized fluorescein fluorophore sticks out into the aqueous environment. Because of its depth of penetration of the membrane, $\mathbf{2 0}$ can respond to the electric field caused by a large fraction of the membrane potential. Molecular-scale electric 110 fields are known to control PET rates very strongly. ${ }^{81}$

\section{Multiple targets}

Given the molecular engineering backdrop to the fluorescent PET sensor/switch principle, chemical emulation of physical devices 15 was an associated discipline from the early days. While logic devices receive a lot of airtime, ${ }^{16}$ some attention has to be given to their components. The triode, ${ }^{82}$ which is one of those, is a three-electrode assembly where the input to one electrode influences the output from another. We arrange something similar 120 by using a 'fluorophore-spacer 1 -receptor 1 -spacer 2 -receptor ${ }_{2}$ ' system $21,{ }^{83}$ where receptor ${ }_{1}$ and receptor 2 target $\mathrm{H}^{+}$and $\mathrm{Na}^{+}$ respectively. However, only receptor ${ }_{1}$ is PET-active. The upshot is that a sigmoidal fluorescence intensity $-\mathrm{pH}$ profile is tuned by altering $\mathrm{Na}^{+}$concentration. Electrostatic repulsion between the 25 receptor 1 -bound $\mathrm{H}^{+}$and receptor 2 -bound $\mathrm{Na}^{+}$is responsible for this tuning by influencing the $\mathrm{pK}_{\mathrm{a}}$ value of the sensor. It is only fair to note that Gust, Moore, Moore and their colleagues published an all-photonic triode emulation in $2010 .^{84}$

AND logic gate 22 ${ }^{85}$ due to Farrugia and Magri, contains an 
amine moiety to interact with $\mathrm{H}^{+}$and a ferrocene moiety to respond to redox inputs. Both moieties are PET-active and fluorescence is weakened as a result. Arrest of both these PET pathways by the provision of $\mathrm{H}^{+}$and an oxidizing equivalent 5 leads to switching 'on' of fluorescence. However there is a residual PET process from the fluorophore to the ferricinium moiety (in the oxidized form of 22), which puts an upper limit on the $\mathrm{FE}_{\mathrm{H}+\text {,redox }}$ value. $\mathbf{2 2}$ is logically extended to $\mathbf{2 3 ^ { 8 6 }}$ by Magri and his colleagues. They do it by the addition of a PET-active 10 benzocrown ether receptor to interact with $\mathrm{Na}^{+}$inputs. $\mathrm{A} \mathrm{H}^{+}$, redox, $\mathrm{Na}^{+}$-driven AND gate is the result, which would become a 'lab-on-a-molecule' ${ }^{87}$ for direct detection of some cancers which possess elevated $\mathrm{H}^{+}, \mathrm{Na}^{+}$and free iron.

The original approach to a 'lab-on-a-molecule'87 exploited a 15 small set of selective receptors which communicated intramolecularly with a fluorophore, which then provided a binary readout to a human observer. At least conceptually, this approach can be modified to contain a set of relatively nonselective receptors, e.g. phenylboronic acids to tackle a set of

20 sugar-based drugs. In compensation, a set of fluorophores can be built into the supermolecule so that the fluorescence intensities at several wavelengths serve as readouts. The intensity patterns can be chemometrically analyzed ${ }^{88}$ for further sharpening of the results so that the drugs become distinguishable with confidence.

${ }_{25}$ Margulies' $\mathbf{2 4}^{89}$ is the first successful case of this kind, showing that several of the imaginable pitfalls due to the complexity of the structures do not arise. Though the design is broad enough to embrace multiple photochemical mechanisms, PET remains at its heart since several arylmethylamine ${ }^{1,90}$ units are present within

30 24. The binding of sugar-based drugs to aminomethylphenylboronic receptors will then affect fluorescence intensities at a primary level. An internal charge transfer (ICT) mechanism ${ }^{7,91}$ also affects fluorescence intensities at some wavelengths at a primary level due to the presence of a

35 fluorophore with push-pull groups. Electronic energy transfer (EET) between the different fluorophores serves to modulate the fluorescence intensity pattern at a second level.

As found in several cases within section 5, the bispicolylamine moiety also stars within Akkaya's $\mathbf{2 5}^{92}$ where PET is arranged to 40 occur from the bispicolylamine unit to the BODIPY fluorophore. However, the special feature of this work is that $\mathrm{Zn}^{2+}$ is supplied to 25 by a photo-uncaging procedure. ${ }^{93} \mathrm{Zn}^{2+}$ is held within the 'cage' of 26 and is only released when a $360 \mathrm{~nm}$ light dose decomposes 26 to 27 and N-methylpicolylamine The mechanism

${ }_{45}$ here is a rather classical bit of organic photochemistry. The $n \pi^{*}$ triplet excited state of the nitroaryl unit causes an intramolecular hydrogen abstraction via a six-membered ring intermediate. This work has the wider vision of physically integrating molecular logic gates by using metal ions as the linker species. In this ${ }_{50}$ context, the $360 \mathrm{~nm}$ light dose is input. The powerful general complexant EDTA is input 2 . Since EDTA would swallow up any $\mathrm{Zn}^{2+}$ to prevent the fluorescence activation of 25, it serves as a disabling input. Thus $\mathbf{2 6}$ is a light dose, EDTA-driven INHIBIT(EDTA) gate where EDTA is the disabling input2. Its

55 output of $\mathrm{Zn}^{2+}$ then feeds the YES logic gate 25 whose own output is its fluorescence. Similar physical concatenation of logic gates aided by $\mathrm{H}^{+}$was known previously. ${ }^{94,95}$

Molecular keypad locks ${ }^{96}$ are interesting examples of logical molecules which are history-dependent, i.e. the output signal ${ }_{60}$ value depends on the order of addition of the inputs. One way of

arranging this history-dependence is to exploit multivalent interactions so that the full disconnection of complexed species becomes sluggish. Then, several kinetically stable states may appear for a given system. Being replete with aminomethyl${ }_{65}$ phenylboronic acids, Margulies' $24^{89,97,98}$ can engage in such multivalent interactions with inputs chosen from a set of many sugars as well as the catechol derivative 28. Thus it can also serve as a molecular keypad lock with new features which are more reminiscent of semiconductor-based counterparts. One of these 70 new features is that inputs can be repeated to result in passwords such as 333 . In the present instance, this means that the intensity pattern obtained by reading at several wavelengths (following chemometric analysis, if necessary) is dependent on the input species concentration, i.e. when the latter is doubled or trebled.

75 Another of these new features is that multiple passwords can be declared as being valid to open the lock. Of course, this requires a separate definition of 'open' and 'closed' states, which is best done from a Boolean standpoint. ${ }^{16}$

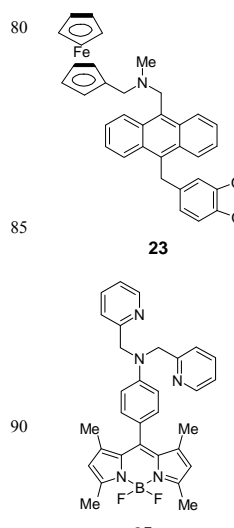

25
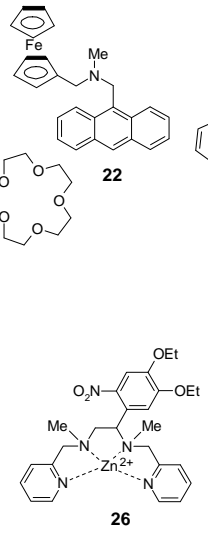

\section{Conclusions and perspectives for future research}

The work surveyed above reveals several trends. One of these is that many fluorescent PET sensor/switch laboratories are 100 augmenting their research with frontier orbital energy calculations conducted through general software. This move to appreciate the physicochemical design aspects is to be applauded, especially because the fluorescent PET sensor/switch principle started off as an exercise in molecular engineering. ${ }^{3}$ Dedicated ${ }_{105}$ papers on calculations are also being published, ${ }^{99,100}$ so that additional insights can be gained. Another of these trends is that a large fraction of the publications are including intracellular evaluations. This move to be involved in the physiological application aspects is important because fluorescent PET sensors 110 are tools. Tools are meant to be used so that they shed light on cellular processes involving the analytes. Tsien's pioneering work along this line remains inspirational. ${ }^{101}$ Just as fluorescent PET sensors are being associated with cells, they can also be anchored on polymer particles of various kinds. ${ }^{102-104}$ Though there is no 115 room for detailed discussion, we cite additional references to the fluorescent PET sensing/switching literature from 2014, ${ }^{105-138}$ where a few cases concerning mechanisms which closely related to PET are also included. 
As noted in the previous paragraph, Tsien's work ${ }^{101}$ still has much to guide future developments in the field of fluorescent PET sensors and switches. For instance, he showed how real time analysis tools of this kind can revolutionize the understanding of 5 intracellular signalling. A valuable lesson from this is that the fluorescent PET sensing community needs to conduct more fluorescence sensing studies in real time. Currently, most studies are reporting single fluorescence micrographs in the presence of the target species. If these can be extended to a set of images in

10 time sequence as the cell goes about its business, the value of the results will be greatly enhanced. During this process, challenges with respect to sensor photostability, sensor survival in the face of cellular processes and calibration of target species concentrations will need to be faced.

15 Further exploitation of fluorescent PET sensors and switches in the future will also benefit if they can operate deeper within tissue. Such multi-cell monitoring can produce important information about cell-cell communication. Two-photon fluorescence versions of fluorescent PET sensors should be able

20 to achieve this by employing red or near-infra red photons for excitation. Once the excited state is produced, the usual PET criteria and arguments would apply. It is a delight to note significant progress in this direction by Kim and colleagues. ${ }^{121-123}$

It is our hope that this review will provide added impetus to 25 research on fluorescence PET sensors/switches. It is clear that the examples published very recently which caught our attention, and which formed the bulk of this review, cover a broad range of targets. This breadth will draw new adherents. When coupled with the continuing commercial success of fluorescence PET 30 sensors for blood electrolytes and gases, ${ }^{38,39}$ it is also clear that this general field will prove attractive to those who want their science to be useful to others.

We are grateful to DEL Northern Ireland, X. G. Ling and L. H. Wang for support and help.

\section{${ }_{35}$ Notes and references}

Address, School of Chemistry and Chemical Engineering, Queen's University, Belfast BT9 5AG, Northern Ireland. Tel: (+)44 289097 4422; Fax: (+)44 289097 4687; E-mail: a.desilva@qub.ac.uk

401 A. P. de Silva and R. A. D. D. Rupasinghe, J. Chem. Soc. Chem. Commun. 1985, 1669.

2 A. P. de Silva and S. A. de Silva, J. Chem. Soc. Chem. Commun. 1986, 1709

3 A. J. Bryan, A. P. de Silva, S. A. de Silva, R. A. D. D. Rupasinghe and K. R. A. S. Sandanayake, Biosensors 1989, 4, 169.

4 A. Weller, Pure Appl. Chem. 1968, 16, 115.

5 Electron Transfer in Chemistry, Vols. 1-5 (Ed. V. Balzani) Wiley$\mathrm{VCH}$, Weinheim, 2001.

6 R. A. Marcus, J. Chem. Phys. 1956, 24, 966.

507 A. P. de Silva, H. Q. N. Gunaratne, T. Gunnlaugsson, A. J. M. Huxley, C. P. McCoy, J. T. Rademacher and T. E. Rice, Chem. Rev. 1997, 97, 1515.

8 A. P. de Silva and S. Uchiyama, Top. Curr. Chem. 2011, 300, 1.

9 Chemosensors (Eds: B. H. Wang and E. V. Anslyn), Wiley, Hoboken, 2011.

10 R. A. Bissell, A. P. de Silva, H. Q. N. Gunaratne, P. L. M. Lynch, G. E. M. Maguire, C. P. McCoy and K. R. A. S. Sandanayake, Top. Curr. Chem. 1993, 168, 223.

11 A. P. de Silva, T. S. Moody and G. D. Wright, Analyst 2009, 134, 2385.

12 A. P. de Silva, H. Q. N. Gunaratne and C. P. McCoy, Nature 1993, $364,42$.

13 Molecular and Supramolecular Information Processing, (Ed: E. Katz), Wiley-VCH, Weinheim, 2012
6514 Biomolecular Information Processing, (Ed: E. Katz), Wiley-VCH, Weinheim, 2012.

15 K. Szacilowski, Infochemistry, Wiley, Chichester, 2012.

16 A. P. de Silva, Molecular Logic-based Computation, Royal Society of Chemistry, Cambridge, 2013.

7017 V. Balzani, A. Credi and M. Venturi, Molecular Devices and Machines. $2^{\text {nd }} \mathrm{Ed}$. VCH, Weinheim, 2008.

18 Molecular Switches. $2^{\text {nd }}$ Ed. (Eds. B. L. Feringa and W. R. Browne) Wiley-VCH, Weinheim, 2011.

19 S. Kenmoku, Y. Urano, K. Kanda, H. Kojima, K. Kikuchi and T. Nagano, Tetrahedron 2004, 60, 11067.

20 K. Yoshida, T. Mori, S. Watanabe, H. Kawai, T. Nagamura, J. Chem. Soc. Perkin Trans. 2 1999, 393.

21 H. Kawai, T. Nagamura, T. Mori, K. Yoshida, J. Phys. Chem. A 1999, 103, 660.

8022 P. Batat, G. Vives, R. Bofinger, R. W. Chang, B. Kauffmann, R. Oda, G. Jonusauskas and N. D. McClenaghan, Photochem. Photobiol. Sci. 2012, 11, 1666.

23 R. A. Bissell, A. J. Bryan, A. P. de Silva and C. P. McCoy, J. Chem. Soc. Chem. Commun. 1994, 405.

8524 S. Uchiyama, K. Iwai and A. P. de Silva, Angew. Chem. Int. Ed. Engl. 2008, 47, 4667.

25 F. M. Harold, The Vital Force: A Study of Bioenergetics Freeman, New York, 1986.

26 N. I. Georgiev, S. M. Dimov, A. M. Asiri, K. A. Alamry, A. Y. Obaid, and V. B. Bojinov, J. Lumin. 2014, 149, 325.

27 L. M. Daffy, A. P. de Silva, H. Q. N. Gunaratne, C. Huber, P. L. M. Lynch, T. Werner and O. S. Wolfbeis, Chem. Eur. J. 1998, 4, 1810

28 R. Sun, X. D. Liu, Z. Xun, J. M. Lu, Y. J. Xu and J. F. Ge, Sensors Actuators B 2014, 201, 426.

9529 Y. Xu, Z. Jiang, Y. Xiao, F. Z. Bi, J. Y. Miao and B. X. Zhao, Anal. Chim. Acta 2014, 820, 146.

30 S. Ast, T. Schwarze, H. Müller, A. Sukhanov, S. Michaelis, J. Wegener, O. S. Wolfbeis, T. Körzdörfer, A. Dürkop, and H. -J. Holdt, Chem. Eur. J. 2013, 19, 14911.

10031 A. P. de Silva and S. A. de Silva, J. Chem. Soc. Chem. Commun. 1986, 1709.

32 J. -P. Konopelski, F. Kotzyba-Hibert, J. -M. Lehn, J. -P. Desvergne, F. Fages, A. Castellan and H. Bouas-Laurent, J. Chem. Soc. Chem. Commun. 1985, 433.

10533 Q. Wang, X. Y. Wang and L. Li, J. Phys. Org. Chem. 2014, 27, 546.

34 T. Schwarze, C. Dosche, R. Flehr, T. Klamroth, H. G. Lohmannsroben, P. Saalfrank, E. Cleve, H. J. Buschmann and H. -J. Holdt, Chem. Commun. 2010, 46, 2034.

35 P. Kaur, N. Kaur, M. Kaur, V. Dhuna, J. Singh and K. Singh, RSC Adv. 2014, 4, 16104

36 A. P. de Silva and K. R. A. S. Sandanayake, J. Chem. Soc. Chem. Commun. 1989, 1183.

37 M. Vonlanthen, C. M. Connelly, A. Deiters, A. Linden and N. S. Finney, J. Org. Chem. 2014, 79, 6054.

11538 J. K. Tusa and H. He, J. Mater. Chem. 2005, 15, 2640.

39 www.optimedical.com.

40 A. Fernandez-Gutierrez and A. Muñoz de la Pena, in Molecular Luminescence Spectroscopy. Methods and Applications. Part 1 (Ed. S. G. Schulman), Wiley, New York, 1985, p 371

12041 M. J. Culzoni, A. Muñoz de la Peña, A. Machuca, H. C. Goicoechea, R. Brasca and R. Babiano, Talanta 2013, 117, 288.

42 J. B. Wang and X. H. Qian, Org. Lett. 2006, 8, 3721.

43 X. H. Qian, Y. Xiao, Y. F. Xu, X. F. Guo. J. H. Qian and W. P. Zhu, Chem. Commun. 2010, 6418.

12544 Y. M. Liu, Q. Fei, H. Y. Shan, M. H. Cui, Q. Liu, G. D. Feng and Y. F. Huan, Analyst 2014, 139, 1868.

45 S. A. de Silva, A. Zavaleta, D. E. Baron, O. Allam, E. V. Isidor, N. Kashimura and J. M. Percarpio, Tetrahedron Lett. 1997, 38, 2237.

46 K. Rurack, Spectrochim. Acta A 2001, 57, 2161.

13047 L. Fabbrizzi, M. Licchelli and P. Pallavicini, Acc. Chem. Res. 1999, 32,846

48 H. Kim, J. Kang, K. B. Kim, E. J. Song and C. Kim, Spectrochim. Acta A: Mol. Biomol. Spectrosc. 2014, 118, 883.

49 D. Y. Liu, J. Qi, X. Y. Liu, H. R. He, J. T. Chen and G. M. Yang, Inorg. Chem. Commun. 2014, 43, 173.

50 R. Parkesh, T. C. Lee and T. Gunnlaugsson, Org. Biomol. Chem. $2007,5,310$. 
51 A. K. Lal and M. D. Milton, Tetrahedron Lett. 2014, 55, 1810.

52 M. Q. Tian, H. Ihmels and K. Benner, Chem. Commun. 2010, 46, 5719.

53 Q. C. Liu, C. Liu, L. F. Chang, S. He, Y. Lu and X. S. Zeng, RSC Adv. 2014, 4, 14361.

54 S. Madhu and M. Ravikanth, Inorg. Chem. 2014, 53, 1646.

55 P. Ashokkumar, H. Weißhoff, W. Kraus, and K. Rurack, Angew. Chem. Int. Ed. 2014, 53, 2225.

56 T. Gunnlaugsson, P. E. Kruger, P. Jensen, J. Tierney, H. D. P. Ali and G. M. Hussey, J. Org. Chem. 2005, 70, 10875

57 R. M. Duke and T. Gunnlaugsson, Tetrahedron Lett. 2007, 48, 8043

58 A. P. de Silva, H. Q. N. Gunaratne and T. Gunnlaugsson, Tetrahedron Lett. 1998, 39, 5077.

59 J. K. Weltman, R. P. Szaro, A. R. Frackelston, R. M. Dowben, J. R. Bunting and R. E. Cathou, J. Biol. Chem. 1973, 218, 3173.

60 T. Matsumoto, Y. Urano, T. Shoda, H. Kojima and T. Nagano, Org. Lett. 2007, 9, 3375.

61 X. F. Yang, Q. Huang, Y. G. Zhong, Z. Li, H. Li, M. Lowry, J. O. Escobedo and R. M. Strongin, Chem. Sci. 2014, 5, 2177.

2062 Y. S. Guan, L.Y. Niu, Y. Z. Chen, L. Z. Wu, C. H. Tung and Q. Z. Yang, RSC Adv. 2014, 4, 8360.

63 J. Liu, Y. Q. Sun, H. X. Zhang, Y. Y. Huo, Y. W. Shi and W. Guo, Chem. Sci. 2014, 5, 3183.

64 M. Işık, R. Guliyev, S. Kolemen, Y. Altay, B. Senturk, T. Tekinay and E. U. Akkaya, Org. Lett. 2014, 16, 3260.

65 T. Guo, L. Cui, J. N. Shen, R. Wang, W. P. Zhu, Y. F. Xu and X. H. Qian, Chem. Commun. 2013, 49, 1862

66 J. Kim and Y. Kim, Analyst 2014, 139, 2986

67 F. N. Lu and T. Nabeshima, Dalton Trans. 2014, 43, 9529.

3068 Z. Q. Ye, R. Zhang, B. Song, Z. C. Dai, D. Y. Jin, E. M. Goldys and J. L. Yuan, Dalton Trans. 2014, 43, 8414

69 R. Zhang, B. Song, Z. C. Dai, Z. Q. Ye, Y. N. Xiao, Y. Liu and J. L. Yuan, Biosens. Bioelectron. 2013, 50, 1.

70 T. Y. Liu, X. G. Liu, D. R. Spring, X. H. Qian, J. N. Cui and Z. C. Xu, Sci. Rep. 2014, 4, 5418.

71 W. Rettig, Top. Curr. Chem. 1994, 169, 253.

72 Z. R. Grabowski and J. Dobkowski, Pure Appl. Chem. 1983, 55, 245

73 S. Zheng, T. S. Moody, P. L. M. Lynch, H. Q. N. Gunaratne, T. E. Rice and A. P. de Silva, Photochem. Photobiol. Sci. 2012, 11, 1675.

4074 A. P. de Silva, H. Q. N. Gunaratne, T. Gunnlaugsson and P. L. M. Lynch, New J. Chem. 1996, 20,871.

75 R. A. Bissell, A. P. de Silva, W. T. M. L. Fernando, S. T. Patuwathavithana and T. K. S. D. Samarasinghe, Tetrahedron Lett 1991, 32, 425

4576 H. Sunahara, Y. Urano, H. Kojima, and T. Nagano, J. Am. Chem. Soc. 2007, 129, 5597.

77 C. J. Fahrni, L. C. Yang and D. G. VanDerveer, J. Am. Chem. Soc. 2003, 125, 3799.

78 E. W. Miller, J. Y. Lin, E. P. Frady, P. A. Steinbach, W. B. Kristan

$50 \quad$ and R. Y. Tsien, Proc. Natl. Acad. Sci. USA 2012, 109, 2114

79 A. P. de Silva, Nature Chem. 2012, 4, 440.

80 W. B. Davis, W. A. Svec, M. A. Ratner and M. R. Wasielewski, Nature 1998, 396, 60.

81 A. P. de Silva, H. Q. N. Gunaratne, J. -L. Habib-Jiwan, C. P. McCoy,

55 T. E. Rice and J. -P. Soumillion, Angew. Chem. Int. Ed. Engl. 1995, 34, 1728.

82 E. Hughes, Electrical Technology, 6th Ed., Longman, Burnt Mill, 1990.

83 A. J. M. Huxley, M. Schroeder, H. Q. N. Gunaratne and A. P. de Silva, Angew. Chem. Int. Ed. 2014, 53, 3622.

84 A. E. Keirstead, J. W. Bridgewater, Y. Terazono, G. Kodis, S. Straight, P. A. Liddell, A. L. Moore, T. A. Moore and D. Gust, J. Am. Chem. Soc. 2010, 132, 6588.

85 T. J. Farrugia and D. C. Magri, New J. Chem. 2013, 37, 148

6586 D. C. Magri, M. Camilleri Fava and C. J. Mallia, Chem. Commun 2014, 50, 1009

87 D. C. Magri, G. J. Brown, G. D. McClean and A. P. de Silva, J. Am. Chem. Soc. 2006, 128, 4950.

88 A. T. Wright and E. V. Anslyn, Chem. Soc. Rev. 2006, 35, 14.

7089 B. Rout, L. Unger, G. Armony, M. A. Iron and D. Margulies, Angew. Chem. Int. Ed. 2012, 124, 12645.

90 T. D. James, K. R. A. S. Sandanayake and S. Shinkai, J. Chem. Soc. Chem. Commun 1994, 477.
91 B. Valeur and M. N. Berberan-Santos, Molecular Fluorescence. $2^{\text {nd }}$ Ed, Wiley-VCH, Weinheim, 2012.

92 E. T. Ecik, A. Atilgan, R. Guliyev, T. B. Uyar, A. Gumusa and E. U. Akkaya, Dalton Trans. 2014, 43, 67.

93 J. H. Kaplan and G. C. R. Ellis-Davies, Proc. Natl. Acad. Sci. USA 1988, 85, 6571

8094 F. M. Raymo and S. Giordani, Org. Lett. 2001, 3, 3475.

95 S. Giordani, M. A. Cejas and F. M. Raymo, Tetrahedron 2004, 60, 10973 .

96 D. Margulies, C. E. Felder, G. Melman and A. Shanzer, J. Am. Chem. Soc. 2007, 129, 347.

8597 B. Rout, P. Milko, M. A. Iron, L. Motiei and D. Margulies, J. Am. Chem. Soc. 2013, 135, 15330 .

98 B. Rout, L. Motiei and D. Margulies, Synlett 2014, 25, 1050.

99 H. Z. Su, X. B. Chen and W. H. Fang, Anal. Chem. 2014, 86, 891.

100 H. Lee, R. D. Hancock and H. S. Lee, J. Phys. Chem. A 2013, 117, 13345.

101 R. Y. Tsien, Am. J. Physiol. 1992, 263, C723.

102 M. Ayadim, J. -L. Habib-Jiwan, A. P. de Silva and J. -P. Soumillion, Tetrahedron Lett. 1996, 37, 7039.

103 A. P. de Silva, M. R. James, B. O. F. McKinney, D. A. Pears and S. M. Weir, Nature Mater. 2006, 5, 787.

104 Y. F. Li, Y. F. Wei, Y. Tan, X. F. Kong, K. Zhou, Z. M. Wu and Y. J. Liu, Anal. Sci. 2014, 30, 257.

105 S. T. Manjare, S. Kim, W. D. Heo and D. G. Churchill, Org. Lett. 2014, 16, 410.

100106 S. T. Manjare, J. Kim, Y. Lee and D. G. Churchill, Org. Lett. 2014, 16, 520 .

107 S. T. Manjare, Y. Kim and D. G. Churchill, Acc. Chem. Res. 2014, 47, 2985 .

108 D. P. Murale, S. T. Manjare, Y. S. Lee and D. G. Churchill, Chem. Commun. 2014, 50, 359.

109 Z. R. Lou, S. Q. Yang, P. Li, P. W. Zhou and K. L. Han, Phys. Chem. Chem. Phys. 2014, 16, 3749.

110 H. Zhu, J. L. Fan, J. Y. Wang, H. Y. Mu and X. J. Peng, J. Am. Chem. Soc. 2014, 136, 12820.

110111 M. Elstner, J. Axthelm and A. Schiller, Angew. Chem. Int. Ed. 2014, 53, 7339 .

112 A. Bamesberger, C. Schwartz, Q. Song, W. W. Han, Z. Wang and H S. Cao, New J. Chem. 2014, 38, 884.

113 N. Kaur, P. Kaur and K. Singh, RSC Adv. 2014, 4, 29340.

115114 S. Y. Lim, K. H. Hong, D. I. Kim, H. Kwon, and H. J. Kim, J. Am. Chem. Soc. 2014, 136, 7018.

115 M. Kaur, P. Kaur, V. Dhuna, S. Singh and K. Singh, Dalton Trans. 2014, 43, 5707.

116 P. Kaur and K. Singh, RSC Adv. 2014, 4, 11980.

120117 P. W. Jin, C. H. Jiao, Z. Q. Guo, Y. He, S. Q. Zhu, H. Tian and W. H. Zhu, Chem. Sci. 2014, 5, 4012.

118 W. Zhang, Z. Ma, L. P. Du and M. Y. Li, Analyst 2014, 139, 2641.

119 L. Qiu, C. C. Zhu, H. C. Chen, M. Hu, W. J. He and Z. J. Guo, Chem. Commun. 2014, 50, 4631.

125120 Y. J. Jang, O. G. Tsay, D. P. Murale, J. A. Jeong, A. Segev and D. G. Churchill, Chem. Commun. 2014, 50, 7531.

121 A. R. Sarkar, C. H. Heo, M. Y. Park, H. W. Lee and H. M. Kim, Chem. Commun. 2014, 50, 1309.

122 A. R. Sarkar, D. E. Kang, H. M. Kim and B. R. Cho, Inorg. Chem. 2014, 53, 1794

123 X. H. Dong, C. H. Heo, S. Y. Chen, H. M. Kim and Z. H. Liu, Anal. Chem. 2014, 86, 308

124 X. D. Liu, C. Fan, R. Sun, Y. J. Xu and J. F. Ge, Anal. Bioanal. Chem. 2014, 406, 7059

135125 R. Sun, X. D. Liu, Z. Xun, J. M. Lu, Y. J. Xu and J. F. Ge, Sensors Actuators B-Chem. 2014, 201, 426.

126 J. T. Hutt and Z. D. Aron, J. Chem. Educ. 2014, 91, 1990.

127 S. M. Dimov, N. I. Georgiev, A. M. Asiri and V. B. Bojinov, J. Fluoresc. 2014, 24, 1621.

140128 J. Nandre, S. Patil, V. Patil, F. B. Yu, L. X. Chen, S. Sahoo, T. Prior, C. Redshaw, P. Mahulikar and U. Patil, Biosensors Bioelectron. 2014, 61, 612.

129 S. Chakravarty, D. Saikia, P. Sharma, N. C. Adhikary, D. Thakur and N. S. Sarma, Analyst, 2014, 139, 6502.

145130 L. J. Liang, L. C. Zhao and X. S. Zeng, J. Fluoresc. 2014, 24, 1671. 
131 J. B. Lin, C. H. Zhu, X. Q. Liu, B. Chen, Y. Y. Zhang, J. P. Xue and J. Y. Liu, Chinese J. Chem. 2014, 32, 1116.

132 S. Karakaya and F. Algi, Tetrahedron Lett. 2014, 55, 5555.

133 X. H. Liu, L. Jiang, J. S. Li, L. Wang, Y. Yu, Q. Zhou, X. X. Lv, W. M. Gong, Y. Lu and J. Y. Wang, J. Am. Chem. Soc. 2014, 136, 13094.

134 D. Aigner, S. A. Freunberger, M. Wilkening, R. Saf, S. M. Borisov and I. Klimant, Anal. Chem. 2014, 86, 9293.

135 P. Srivastava, S. S. Razi, R. Ali, R. C. Gupta, S. S. Yadav, G. Narayan and A. Misra, Anal. Chem. 2014, 86, 8693

136 S. Malkondu, Tetrahedron 2014, 35, 5580.

137 R. Gotor, A. M. Costero, P. Gavina and S. Gil, RSC Adv. 2014, 4, 15975.

138 R. Gotor, P. Gavina, L. E. Ochando, K. Chulvi, A. Lorente, R.

15 Martinez-Manez and A. M. Costero, Dyes Pigm. 2014, 108, 76.

Table of Contents Graphic

20

Fluorophore

Spacer Recepto

25 Table of Contents Entry

Fluorophores can be combined with receptors according to a molecular engineering design to yield fluorescent sensing and switching devices.

\section{Group photograph}

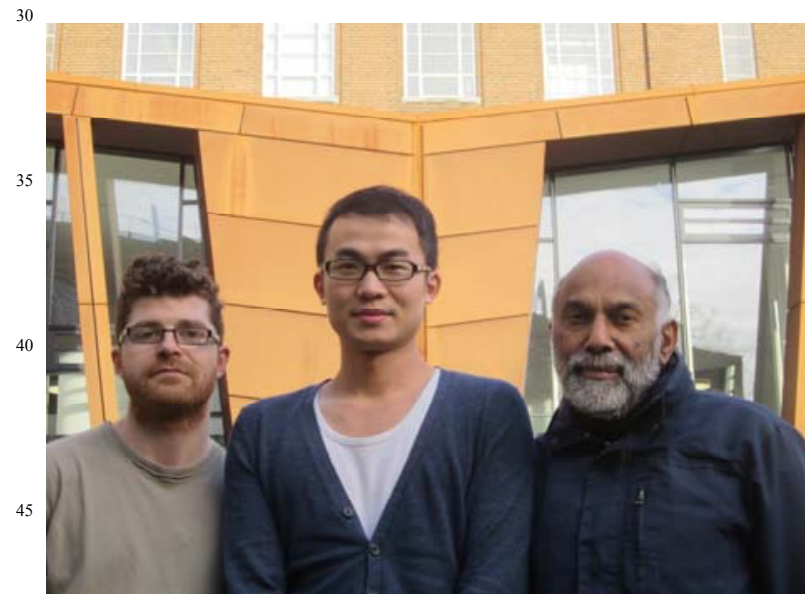

\section{Biography}

${ }_{50}$ The authors came to study for their PhD at Queen's University Belfast, Northern Ireland, from places as far apart as Zhenjiang, Belfast and Colombo.xx Besides the chemistry day jobs, Brian (left) brings up his two daughters, Jue (centre) plays basketball and AP (right) plays percussion with an Irish traditional band. 